\title{
Body capital in Brazilian football end American Basketball*
}

\author{
Antonio Jose Müller** \\ Adolfo Ramos Lamar***
}

\section{Abstract}

There is a relationship between athlete biotype and sports activity in which the body plays. There is also a relationship between the dominant culture, the body and its capital, the body is properly built to play its role in certain particular culture valued by sport. Moreover, exist a huge influence of sports in children's motivation for education; however, this influence can be negative if children are not using sports for academic purpose, but only a false dream to be a professional player. This paper aims to discuss the importance of capital in the body according to the prevailing culture in Brazil and the USA. To do so, compare features of two sports, basketball and football in the USA in Brazil, according to the cultural importance of sport and its practitioners. Therefore characterizes the importance of blacks, their bodily features, their typical culture in American basketball, as well as body building in Brazilian football within a company dedicated to capital that these sports represent these cultures.

Keywords: Body Capital. Sport in Society. Sport and Education.

\footnotetext{
* O texto é parte integrante da Tese de doutorado em Educação pela University of Texas at El Paso, com o título "Body Capital - USA-Brazil cross-cultural study of sport and academic motivation".

** Professor da FURB - Blumenau, SC nos cursos de Graduação e Pós-graduação em Educação Física e Educação. Doutor em Educação pela University of Texas at El Paso, Especialista em treinamento desportivo - Voleibol, pela UNIG e graduado em Educação Física pela FURB. E-mail: antoniomuller2@hotmail.com

*** Pós-doutor em Educação pela Universidade de São Paulo - USP. Doutor em Educação pela Universidade de Campinas - UNICAMP. Professor do programa de pós-graduação em Educação da Fundação Universidade Regional de Blumenau -FURB. E-mail: ajemabra@yahoo.com
} 


\section{O capital do corpo no basquetebol americano e no futebol brasileiro}

\section{Resumo}

Existe uma relação entre biotipo do atleta e a atividade esportiva do qual o corpo desempenha. Existe ainda uma relação entre a cultura preponderante, o corpo e o seu capital, ou seja, o corpo está adequadamente construído para desempenhar o seu papel em determinado esporte valorizado por determinada cultura. Além disso, existe uma grande influência do esporte na motivação das crianças para a educação; no entanto, essa influência pode ser negativa, caso as crianças não usarem o esporte para fins acadêmicos e sim como um sonho, um falso sonho, de um dia se tornarem atletas profissionais. Este texto tem o objetivo de discutir a importância do capital do corpo de acordo com a cultura predominante no Brasil e nos USA. Para tanto, compara duas características dos esportes, basquetebol nos EUA e futebol no Brasil, de acordo com a importância cultural destes esportes e de seus praticantes. Assim, caracteriza a importância dos negros, suas características corpóreas, sua cultura típica no basquetebol americano, bem como a construção do corpo no futebol brasileiro dentro de uma sociedade voltada ao capital que estes esportes representam nestas culturas.

Palavras-chaves: Capital do Corpo. Esporte na Sociedade. Esporte e Educação

\section{El capital del cuerpo en el baloncesto americano y en el fútbol brasileño}

\section{Resumen}

Existe una relación entre biotipo del atleta y la actividad deportiva en la que el cuerpo desempeña. Hay todavía una relación entre la cultura dominante, el cuerpo y su capital, es decir, el cuerpo está construido adecuadamente para desempeñar su papel en determinado deporte valorado por cierta cultura. Además, hay una gran influencia del deporte en la motivación de los niños para la educación; sin embargo, esta influencia puede ser negativa si los niños no utilizan el deporte para fines académicos, sino como un sueño, un falso sueño, de algún día convertirse en atletas profesionales. Este texto tiene como objetivo discutir la importancia del capital del cuerpo a la cultura imperante en Brasil y los EE.UU.. Para ello, compara dos características de los deportes, el baloncesto en los EE.UU. y el fútbol en Brasil, de acuerdo con la importancia cultural de eses deportes y de sus practicantes. Por lo tanto caracteriza a la importancia de los negros, sus características corporales, su cultura típica en el baloncesto estadounidense, así como la construcción del cuerpo en el fútbol brasileño, dentro de una sociedad dedicada al capital que estos deportes representan en esas culturas.

Palabras clave: Capital del Cuerpo. Deporte en la Sociedad. Deporte y Educación 


\section{Introduction}

Human history is connected with sport and whenever and however sports arose in any particular age, they were usually said to be central to the development of human character, and they seemed to accrete to themselves all sorts of deferential higher ideals, like purity of purpose and nobility (MACGREGOR, 2004). Through human history the simple seems less important. Athletes have been searching for an edge since we started keeping score, from the herbs and hallucinogenic fungi ingested by ancient Greeks to the strychnine swallowed by Roman gladiators. During the Gladiatorial games, "athletes" fought against criminals and beasts to provide entertainment for the people and to maintain social status and social order. It was a sanguinary battle to survive. Given the growth of prize and endorsement money, it's not surprising that this win-at-all-costs ethos has become persistent (SMITH, 2004).

Today, professional athletes and coaches are confronting a similar situation. They are surviving only if they win. Continuing to lost means you are unsuccessful, and it is the beginning of "professional dying." Bodies are the center of physical education and sport. However, bodies are also a form of identity, are socially produced, or constructed and a site of social difference and division (HAYES and STIDDER, 2003). Usually this involves a constant process of imitation by the lower classes of higher-class habits, and it is a reproduction of higher-class power and privilege.

There is an important relationship between sport and culture. Some cultures are expressed by the sport itself or by the type of sport that is appreciated and popular in a particular region of the planet. Anthropologically, the sport is present in our everyday lives, but some sports are more related to the type of "tribe" that practice. This practice determines the object of study and attempts to explain why certain cultures exploit the specific biotype according to the most prized sport. This aspect enhances certain bodies over others. Therefore, in the United States, where basketball is important, the biotype and the most valued motor skills are related to the characteristics required for basketball, such as height and agility. Similarly, in Brazil where football is the first sport, the biotype and motor skills as medium height and ball control, determine the ideal body for the sport.

This text explores this cultural relationship in both countries cited above, with the intention of discussing how the athlete's body is valued u despised according to each society. Further, it discusses the influence of sport on (un) motivation of children to education. To do so, compare features of two sports, basketball and the influence of blacks in America and football in Brazil, as an opportunity for social and economic ascension to the poorest. Therefore characterizes the importance of blacks, their bodily features, their typical culture in American basketball, as well as body building in Brazilian football within a company dedicated to capital that these sports represent these cultures.

First, we will discuss the importance of the body and its capital in the culture and sport. Subsequently, we will present the sport as a social phenomenon, and media exploitation. Continuing, we will discuss the history of basketball in the USA and the influence of black culture in this sport. Likewise, we will present cultural influences of football in Brazil. In conclusion, we will present some suggestions for the sport better connected with education, according to the philosophy of Paulo Freire.

\section{Body Capital}

Body capital is our individual, physical, and public connection, which sport provides a means of obtaining from the body (corpore) a form of consent that the mind (mens) could refuse (BOURDIE, apud DUNNING, et al., 1993). The relations between bodily disciplines, habits, ceremonies and power and their numerous manifestations in both pleasurable social forms and oppressive forms vary between societies. Bodily manifestations constitute and express the relative powers of classes, regions, racial, and ethnic groups, and genders. This could only win legitimacy as a cultural project if it could be harmonized with new class needs for labor discipline, education, and the control of public order.

Since sports participation provides a focus for social activity, an opportunity to make friends, develop networks 
and reduces social isolation, it seems well placed to support the development of social and body capital.

The dominant cultural features of this self-consciously modern form of sporting practice centered on two distinct concepts of discipline: 1) the notion of self-discipline through the exercise of a person's supposedly higher faculties of reason and 2) the disciplinary bodily mastery achieved through techniques that were synthesized into a new kind of culture to live life in a certain form.

In this way, the perfectly proportioned bodies of Greek male athletes, revealed in the paintings and sculptures became the idealized bodily aesthetic (DUNNING, et al., 1993). In modern days, body is style and their characteristics define the position in society. Since each culture values specific physical characteristics, the perfection of bodies is less important than are the physical characteristics for a particular sport or activity in particular society.

Some of the capital that poor pupils have is their bodies. But, not every pupil is talented or physically prepared to use his/her body capital in specific sport. The key point is that body capital limitations can reproduce class inequalities. During Physical Education classes teachers must prevent these limitations by addressing issues of social deprivation and disadvantage promoting social inclusion for all variety of bodies.

Body capital has some of negative dimensions. Two obvious factors may be addressed: (1) body capital may be impermanent. Many athletes prematurely interrupted their careers because of injuries. Also, sooner or later everyone who plays professional sorts must quit. The worst part is they have no background in different fields and are suffering to maintain their lives at the same level they had with astronomic salaries. Different from artists which can have a "longer professional life" many athletes were quickly fails in the forgetful and depression. It is the die of a life of glory, money, and admiration and reborn in a regular life and not everyone know how to hold it. And (2) schools use body capital to generate capital. Athletes are used for exploitation to raise money for schools or companies and/or generate school spirit literally on the bodies/backs of athletes.
Body capital is also discriminatory where there is a strong downside as those controlling the images of the body. Media and corporation define what is normal and beautiful and making fortunes based on that control.

Body capital has many different definitions and applications. Society is a point that defines body capital. For instance, football in Brazil is a sport predominantly played by poor blacks/mulatos and male. In the U.S. football is predominantly played by middle class white girls. Therefore, to be successful in a specific culture, body capital must follow what kinds of talents or skills are socially constructed. Let's use music to compare: U.S. population appreciates jazz and Brazilians appreciate samba because of the historical and cultural background. In sport, Brazilian society will recognize a talented player in football more than in American football because of the cultural importance of football in that country. Brazilian football player has unique corporal movement which follows the cultural appreciation of its population as the same in the U.S. for football players. If one football player tries to play football in Brazil he probably will be in trouble in the "eyes" of Brazilians, because of the different style or movements which are important characteristics in American football rather than football.

Sport is a form of societal expression and each society has a sport or sports as a mirror (MELO, 2000). Therefore, the objective in this research is to understand body capital as physical expressions which are socially and culturally constructed in each country.

\section{The phenomenon of sports}

The phenomenon of sport is an important role for millions of people worldwide. Around the world many people enjoy playing, watching and discussing a variety of sports. Sport occupies a prominent place in different cultures and has significant social influences. According to Simon (1985) sport is a significant form of social activity, and sport affects the educational system, the economy, and the citizens' values. Especially in the present time, the social impact and significance of sport is massive. Snyder and Spreitzer (1978) summarize that the phenomena of sport have emerged in the last twentieth 
century to become one of the most pervasive social institutions in contemporary societies.

This study may be significant for its description of life circumstances that express particular social issues (MARSHAL and ROSSMAN, 1999. By exploring sport-education in depth, this research has the potential to promote social integration and academic motivation, since UNESCO in 1976 recognized the importance of sport as indispensable for the permanent education of people (TUBINO, 2001). This study also identifies potential alternatives of policy and practices, such as student participation in sports related to satisfactory progress in academics, in order to provide options that support and promote learning opportunities according to regional differences. The use of certain social influences may be subject to greater examination as a result of new knowledge and understanding of sport opportunities. Lastly, the current conversation about sport and social inclusion may have to be viewed from a broader perspective to understand how low socioeconomic groups can receive socioeconomic or educational opportunities through sport.

Historically, sport has become a popular expression of culture. Some countries are recognized either because of the good quality of a specific sport that their population plays or enjoys, or because of the connection between sport and society in a specific culture. The concept of sport is not just excitement, fanaticism, and enthusiasm, but also social participation where economic, political and educational impact is included. Moreover, for many poor or segregated people, sports appear to be one of the few allowable and available opportunities for success in a perceived racist and oppressive society (SAILES, 1984).

However, the connection between sport and society could be better explored in schools as a motivational factor. In Brazil and in the United States some students are out of school or unmotivated with the educational process for many different reasons, such as economic problems, social problems, or problems related to curriculum. Particularly in Brazil this problem is more complex where the number of dropouts and grade retention is very high - about 41 percent and 32 percent respecti- vely in the $8^{\text {th }}$ grade, by the end of mandatory education. Moreover, 41 percent of the students do not finish the ensino fundamental (elementary and middle school) (Instituto Nacional de Pesquisas Educacionais (INEP, 2003). According to the National Center for Education Statistics (NCES, 2000) in the United States, the number of dropouts is 4.8 percent and grade retention is 13.5 percent in high school and below. The problem in the U.S. is the accountability system. With accountability system based on testing results and also to a lack of adequate funds available, there is a decline in the importance of extra-curricular activities, such as sports and music and expanding more time and preoccupation in test results in detriment of students' appreciation.

In order to minimize these factors school could get more connected to the specific culture or students' culture. Schools could minimize the gap between students' interest outside of schools and their interest in the curriculum of schools. One example to explain my point is that one teacher in Brazil was working with retained students. She lacked the appropriate experience and students had a very little reading and writing progress. One day she perceived that students were talked enthusiastically about football. Then, she bought a sport journal and started reading to the students. First, the boys started to pay attention and then the girls started to ask about the game or their favorite teams. She began to use the sport journal as what Freire calls "generator themes." For the first time, the teacher gave a meaning for reading and writing literacy, which never happened for the students. "Zico made a goal" began more relevant than "grandmother saw the grapes." Consequently, all class had been promoted to the next level and learned how to read and write (ALVES; GARCIA and CARRANO, 2000). The passion for football developed an opportunity for kids to learn how to read and write because they conducted their own literacy.

Curriculum must respect cultural backgrounds that students bring when they go to school. As Freire (1998), says "why not establish an 'intimate' connection between knowledge considered basic to any school curriculum and knowledge that is the fruit of the lived experience of these students as individuals?" (p. 36). Curriculum has 
the potential to increase motivation since it can take advantage of the student's life experiences and stimulate students to be present and participate in the learning process which could make the school an authentic place of "student-centered instruction." Curriculum theorizing is critical to the development of programs receptive to social and cultural changes in society. There should be the connection of what children practice and enjoy to what is taught in the school curriculum, and a variety of activities that closely relate to the customs and traditions of local life and culture should be incorporated (ROSSATTO, 2001).

Some children prefer to engage in sport or music rather than participate in a regular education. Instead of being in school and acquiring knowledge and academic skills, they would rather be playing because this is much more interesting than going to school. Many reasons cause them to drop out of school. However, they do not give up sports. Mahoney and Cairns (1997) found a relationship between sport participation and school dropout rate, and advocate participation in sport as a means to develop a positive connection to school. Independently from social, gender or racial context, participation in sport can keep students in school and prevent problems related to idle time, such as drugs, violence, pregnancy, boredom, obesity, and a lifelong orientation to wellness. Because sport is a subject that many young people enjoy, schools should increase students' participation in sport to promote and expand educational opportunity. Since sport can be used a vehicle of educational and social opportunities.

Sport, like school, is both an achievement and social domain. The social opportunities inherent in most sports provide opportunities for individuals to develop social relationships and feel that they are part of a group. Children dream of the possibility of participating in professional sports. Further, as evidenced through participation motives and sources to affect, these social opportunities are salient to participants' sport experience and motivation. The implications of the desire for social connections, the goal-directed behavior that may result, and the perceptions of belonging help explain motivation in sport, but, are not well understood (ALLEN, 2003).

\section{Basketball culture in the united states - sport opportunity for racial inequity}

Basketball is very important in U.S. society, either because in the small towns of mid-America, high school basketball often furnished a foundation of common pride, identity, and purpose or basketball flourished in the ethnic and racial enclaves of the extensive metropolises (RADER, 1999).

Class, gender, and race stratification is a fundamental feature of American society, as revealed in the dominance, exploitation, and discrimination of capitalists over workers, of males over females, and of whites over blacks. Moreover, each alone and all in combination are played out in the world of sport (SAGE, 1998).

It is often maintained that professional sport, and arts, more than other occupations, have been areas in which minority groups could have equal opportunity with whites (LANDERS, 1976). In some sports, such as golf and tennis, the access for black people is limited by economic factors, and race discrimination. American sport is shaped by social class stratification in terms of patronage, access, control, and social mobility. Sport contributed in reducing racial segregation.

MacGregor (2004) explained that college sports did more to integrate blacks than Martin Luther King Jr., and, in general, racial discrimination would never be the same. Through his talent and comments, Michael Jordan helped to diminish the discrimination and after Jordan white America discovered they could trust in black men and whites would accept them as one of their own (MacGregor, 2004). This comment tries to explain the benefit of sport in racial issues, but is pure demonstrations of the actual discrimination where black are seem not the same as whites. This also happened in Brazil where whites insist on discriminating against black athletes by using funny, or serious, comments like "Pelé is black, but his soul is white."

One of the most important beliefs in the U. S. was that widespread opportunities existed for individuals to rise above their socioeconomic origins through their own 
skills, hard work, and good fortune. Talamini and Page (2000) defines that sport is a young person's most promising opening into excellence. Unfortunately, deprived youths lacking these advantages were not completely blocked from advancement because they could rely on alternative routes to success. Instead of becoming professionals or entrepreneurs, they might get involved in such activities as religion, politics, crime, and entertainment. These occupations required a lot of talent and drive, and they were not all legitimate (RIESS, 1990).

Differences observed in sport and physical activity participation patterns and performance can be attributed to differences in socioeconomic status. Members of the lower or working class are more likely to view sports as an avenue for social and economic mobility (OLIVER, 1980, apud COAKLEY, 2009). Poor or segregated people have fewer opportunities for a better quality of life, and professional sport provides one of the few ways this can be accomplished (TEICH, 2002). For deprived youth, sports in high school and college can provide an avenue for social and economic mobility.

High schools and large universities are seeking to protect their interests and explore the commercial aspect of sport. Blacks become especially conspicuous at the upper-echelon skill levels of basketball (RADER, 1999). As Sailes (1997) notes, two-thirds of African Americans playing NCAA Division I-A basketball come from impoverished backgrounds. The situation is exploited by the schools. Most basketball programs hired a black assistant coach in order to make a special pitch to black athletes (RADER, 1999). In this situation, African American athletes should use sports to achieve educational goals. However, they use college sports to get their attempt at professional sports (SAILES, 1998). By contrast, sports can contribute to educational development among high school and college student athletes (HARRIS, 1983).

When some underprovided classes have the chance to climb socially through sports they usually "grab" it. Research shows African-Americans in sports, for example, use sports to get a college degree. According to the Sailes (1996) "The group of Division I black female basketball players shows the largest differential in graduation ra- tes between student-athletes and the general student population. They graduated at a rate of 62 percent, 16 percent higher than the black female population, which graduated at a rate of 46 percent. Black male student-athletes, in all sports, also graduated at a significantly higher rate than their counterparts in the overall student body with a graduation rate of 48 percent compared to the general student-body rate of 35 percent." It is my believe that this happens because the minorities take advantages of their chances with more conviction than people from other social classes.

Furthermore, African Americans constitute only $12 \%$ of the United States population yet are overrepresented in collegiate and professional sports. For example, black athletes represent $21 \%$ of professional baseball players, $73 \%$ of the athletes participating in the National Basketball Association, and $57 \%$ of the athletes participating in the National Football League (COAKLEY, 2009). Sport like basketball for African Americans and football for underprivileged Brazilians are popular among poorer people because of the ease of accessibility to facilities. Many researchers and authors have attempted to explain this phenomenon from a number of scientific perceptions such as, black supremacy in sports, giving credibility to the notion that blacks are intellectually inferior to whites, and limiting the number of opportunities for black or poor people only in a few areas outside of sport. This is a recognized racial subjugation by social stereotypes. This social stereotyping practice by the dominant culture precipitated the construction of social barriers to preserve the culture, status and privilege of white society. In fact, black athletic success is not a genetic phenomenon but the results of determination of blacks to overcome perceived arbitrary and deliberately contrived social barriers (SAILES, 1991).

The mass media has a great impact in shaping the values and sports aspirations of youth people. It fills the minds of youth people with the notion that professional sports are attainable. Media sensationalize the achievements of elite athletes, amplifying their glamorous personal lives, enormous salaries, and often the incredible accomplishments of professional athletes are romanticized to the point of fantasy (COAKLEY, 2009). However, sport exerts 
a sedative effect on youth, enticing them into unrealistic expectations about their chances in a professional sport. This expectation can limit their educational progress, putting education as a secondary goal and sport as a priority. Consequently, not having educational skills to fall back on makes the situation worse (SAILES, 1997).

In 1950, the National Basketball Association (NBA), a professional basketball league, was created and a new opportunity of social mobility arose. Gifted superstars survived the ferocious competition in city leagues and developed their skills through long hours of practice; they were motivated by the gratification of immediate prestige at neighborhood playgrounds and the long-term goals of a high school letter, a college scholarship, and eventually a spot in the NBA and escape from poverty (RADER, 1999).

Black athletes dominated the league, and their success has been the product of talent, hard work, and the emulation of positive role models, which have been all too lacking in urban ghettoes. Moreover, black superstars exercised profound influence in the black ghetto culture (RADER, 1999). In addition, professional basketball has transcended racial prejudice by opening up many coaching and executive positions (RIESS, 1990).

Professional basketball provided opportunities for blacks from poor families. However, according to Riess (1990), athletes fared much better, regardless of social origins, because they were so well educated and the success in the long run depended more upon his/her social origins and education than his/her batting average or earned run average.

The social influences on youth motivation and achievement in sport can be influenced by direct and indirect contact with parents, peers, teachers, and the media. Media produces sport heroes, and heroes are making great influences on youth motivation in sport. Weigand (2000) discovers that sporting heroes are the most influential social agent in the adoption of goal orientation for children and adolescents rather than parents, teachers or peers.

Although youths are highly stimulated in childhood, boys and girls who look to their parents for a role mo- del may be disappointed when compared with star athletes. Throughout adolescence youth is in a cultural limbo without a clear place of his/her own. In the identity confusion, sport occupies a unique position. It is a socially accepted activity cutting across various levels of development and social classes. Sometimes the direction is clouded by the common dream of Brazilian and American youth. If he/she is good enough in sport, he/she may drink from the fountain of youth and continue to play forever, even more profitably than if he/she were working became a professional athlete. For male and female youth groping in a morass of ambiguity, sport serves as a guide post from which to cling. Sport is used in the service of a broader interest and fuller life (TALAMINI and PAGE, 2000).

Recruitment patterns in Brazil and in the U.S. are different. In Brazil scouts search for young players in the football clubs (escolinhas), or through just one tryout (peneira), where hundreds of players have a few minutes to show their skills and one chance to try to buy a ticket to success. The American professional basketball player is often discovered on university teams. Because of education, many good American basketball players start from better socioeconomic positions and are initially much better trained for a professional carrier. This is not so for the Brazilian football player. Sometimes they do not finish high school or college. For the majority, sport provides only fleeting social mobility, leaving their educational levels and values unchanged. This social dream, takes on a much greater significance in a traditional, rigidly stratified society, such as Brazilian than in a relatively open social system such as in the United States (TALAMINI and PAGE, 2000). In the U.S. there are greater economic resources, a greater number of professional sports, and specifically, more opportunities provided to student/athletes through scholarships to earn advanced degrees and acquire professional skills outside the sports scenario.

As Dunning (1999) noted, many sport stars from minorities could play a useful, perhaps pivotal, role in the development and application of policies and trends. They could use their star status in an attempt to persuade poor and discriminated people to take formal education more 
seriously than sport, and by campaigning for devoting of funds to the improvement of inner-city schools (p.218). Such policies would lead to a significant equalization of opportunities for poor and black people and, simultaneously, remove a central precondition involved in sociogenesis and persistence of the myth of black sporting superiority and intellectual inferiority.

The acknowledged salience of sports for many young people has meant that provision of sporting opportunities has become an important element in many urban regeneration projects, largely aimed at reducing youth crime by encouraging the positive use of leisure time and capitalizing upon the supposed socio-psychological outcomes of participating in sport.

Moreover, sport is transitional between the social institution of work and play. It also serves a traditional purpose for the individual. Work was once the responsibility of adults and play is the prerogative of children. Confused by the functional ambiguities, youth may find in sport a useful bridge in his/her transition from child to adult, poor to rich, and anyone to "somebody."

\section{Football culture in Brazil}

Brazil is considered the premier football country. Football is a "way of life" for millions of Brazilians and exerts an immense influence in a social context. However, football could be used in a more appropriate way by its inclusion in Brazil's schools. The purpose of this paper is to understand the unique characteristics and social impact of football in Brazil.

Football arrived in Brazil in 1885 by Charles Miller, an Englishman. Initially it was practiced in private clubs by young males from the elite society. After decades of discrimination against poor or black people, it was transformed in 1933 into a professional activity, and it became very popular in schools, factories, and clubs. Football was practiced throughout the country on beaches or fields, and the number of players grew quickly. Football is also easier for the poor to play because it does not take expensive equipment, courts, swimming pools, etc. Kids play football with whatever they can use to kick it such as, orange or cork screw. With its popularity, football was practiced a great deal by the low-income population, where blacks and mulattos were more concentrated, and their participation increased considerably. Football is Brazil's most popular national pastime. It is no surprise that when a boy is born, often the first gift he receives is a football ball. Gender inequality is reproduced in football. Women have almost no opportunity. Football is considered a male sport, and women "do not know how to play" and girls usually play different sports rather than football, to escape of this discriminatory label.

Some authors mention that Brazilian football shows a unique style and quality because of the great physical ability or "foot ability" in physical activities with rhythm and coordination that blacks have (MELO, 2000). This unique ability was a characteristic of slaves that developed the Capoeira (Brazilian martial art) and samba, which are characterized by footsteps to dance or to play under the rhythm of African drums.

To understand Brazilian football, we need to understand Brazil and its people. The combination of race and culture transformed football into a social phenomenon. The Brazilian football style is a reflex of the culture of its people, who dance samba, and use creativity and swing to promote various rhythms and choreographies. Football then is transformed into art and its players into football artists. This agility is valued by the Brazilian popular culture through the dance, capoeira, and football. The suffering people in a nation of ex-slaves had to develop a great capacity of overcoming barriers with imagination (MARANHÃO, 2002).

There are also other factors that can influence football in Brazil, such as: it is easy to play, the rules are simple, and it does not require special equipment or a special location. In other words, it is played on synthetic grass fields, on abandoned land, at more than 2,000 beaches, or even inside the houses with the football ball being made of socks, oranges, or soda lids. Moreover, people with various physical attributes can practice football. This enables many people to play football and through more people playing, it is easier to have quality players. The same cultural aspect can be seen in the U. S. as far as basketball is 
concerned. Both the extensive and intensive practice of a certain sport stimulates the arousal of talented players, who are generally influenced by the environment in which they live. The Brazilian football team is the first team to win the World Cup five times: 1958, 1962, 1970, 1994, and 2002. Brazil has more professional football teams than any other country in the world.

\section{Heroes and illusion}

Football is a mirror of Brazilian society and plays a big role in the covered by the media. Idols are generated by the media and imitated by children. Rich and famous football players believed football was the only way to achieve economic success so now they are the role models that children from a similar background follow.

Great idols of football such as, Pelé, Garrincha, Zico, Romário, Ronaldo, and many others from lower social classes started playing football on dirt fields under poor conditions. They played intensively and their game skill promoted football in Brazil and made Brazil famous throughout the world. This influence is present in the streets of the whole country, where boys from the minorities dream of becoming future football players, and through this dream, they promote the national football culture even more. This dream motivates millions of children to a better life, escaping poverty, because this can be the only way for them to seek a better quality of life. Through football they mix the joy of playing with the suffering of poverty. One may say that this football culture has a bigger influence on people's lives than subjects related to politics or economics (MARANHÃO, 2002).

In accordance with Teich (2002), some players of the Brazilian national football team have a common path: they grew up almost always very poor and with limited schooling, and they had become beyond idols, owners of surprising wealth. If they were not football players, they would probably have the same destination of their old friends in their communities of origin that today are motoboys (young delivery men on motorcycles), van drivers, or would have died in confrontations with the police or drug dealers. Moreover, there is a common sociological concept in Brazil that the only way of social mobili- ty poor people have, especially the dark-skinned ones, is football, music or the drug traffic. In reality, the racial ideas and the social politics in Brazil are historical, and the result is that the "non-whites" had been deprived of instruction, health, income and work (GRAHAM, 1990). Arbena (1988), comments for children and the young of the poorest social classes, financially underprivileged features or institutional bracket, football has an importance in their daily lives beyond simple recreation.

Famous football players represent a myth that social ascendancy occurs through sports. To say that becoming professional football player is a guarantee of wealth is not entirely true. According to the Brazilian Football Association (CBF), only 4.3 per cent of professional football players in Brazil receive more than 4.000 Brazilian reais or US\$1.350.00 per month. The great majority of players (83.4 per cent) receive less than US\$120.00 per month (CALIL, 2012).

\section{Body capital in education}

In Brazil the poor boy dreams in being a football player, to leave misery and to have a better condition of life. This world of football, created by the working-class players themselves, had become a genuine manifestation of popular culture. Despite the great importance of football in the Brazilian culture, it is not used very much inside the schools, where it could have great social impact. Children play football before, during, and after school. However, football is not used as a form of social integration or as a tool to bring children to school and, therefore, promote their academic knowledge. One of the solutions for dropouts or poor performance in school should be the practice of football, aiming to transport something that children appreciate and will promote their educational participation as well. School must be connected to the student's local culture, in order to develop a universal culture. Children's place of origin and their culture are the beginning of the knowledge they get from the world as time goes by. As a consequence, the school could be transformed into a pleasant place in order to stimulate education. Football could be used as a means of liberation and knowledge development and connect what children practice and enjoy to what is taught in schools. 
Football in Brazil is not just a sport. It is an important social cultural expression. Brazilian society was created through the influence of people from different parts of the world. This mixture created a distinctive and successful form of football admired throughout the world. Brazilian football follows history and culture perspectives and shows the style of Brazilian people and how they would like to live.

In Brazil, the possibility for stable social advancement through sport also exists, but it is elusive. The Brazilian higher education system does not have the same structure, resources and power as the U.S. system. Only with a few exceptions, poor people in Brazil do not have an opportunity to use sports to apply for a scholarship in an institution of higher education. University sports are almost non-existent in Brazil. No policies are related to sports and funding for sports as in the U.S. Therefore, sports exert less importance as a social and educational promoter in Brazil than in the United States. The sponsors of Brazilian players do not lend support to the typically American notion that professional sport offers easy routes of mobility for their players. Moreover, football in Brazil is the main professional sport, which makes it a more significant route of mobility than any single sport in the U.S.

Football exerts a great influence on Brazilian society. However, it can be more effectively used in schools to improve students' knowledge and opportunities, especially for underprivileged children or girls. With this perspective, football can exercise its function against social exclusion. The society, through schools, should promote the opportunity that football provides to athletes and poor people. Moreover, football should be better explored to provide opportunities for girls, becoming a promoter of social inclusion and social equality.

Football is of great importance and is very enjoyable for Brazilian children. Educators can use it in a more academic way. The idea of stimulating education through football can also be used to decrease school dropouts and improve students' poor performance.

\section{Conclusion}

This study provides a discussion of sport and education, the ethical dimension of sport, physical activities and sport for all and sport and culture related to athletes' bodies. All these subjects contribute to a better understanding of how sport is intrinsic to several major issues raised by society. The idea of this study is to discuss a more contemporary definition and understanding of sport in USA regarding blacks in basketball and in Brazil relating football and poverty. It is also explored the relationship between sport, society, and education in both countries.

Sport is an important phenomenon in Brazilian and U.S. societies. This chapter has shown that sport is important in our society because it serves as the context for important everyday experiences, and it is related to every major sphere of social life within a society (COAKLEY, 2009). Sport is one of the rare areas of human endeavor that has shown many measurable improvements though the years. It's our bad habit, however, to make sport too important. Organized sports rise and fall on the tide of human fortune certainly, a function of economy and class and circumstance and the availability of leisure time (MACGREGOR, 2004).

Poverty, lack of education, and the absence of good connections did not disqualify anyone from becoming a prize professional player. At the top level of sport, an athlete earned considerably more money over a brief period of time than he/she could have at any other job.

Aspiring athletes tend not to look at the odds of making it to the top or at what happens afterwards, but only at their heroes. In an era of million-dollar salaries, certain youths do leap from the slum to the penthouse. In reality, however, the investment in time and the effort is so great, and the changes of success so remote, that almost all of the hardworking athletes are misappropriating their energies.

The concept of sport as a vehicle of social mobility is largely a cultural fiction unless young athletes are using 
sport as the instrument to secure school and college access and complete their education. In the U.S. the great tragedy of the past two decades is that not many elite athletes, be it for lack of preparation, ability, or interest, are benefiting from their free college education which is the best means for long-term vertical mobility that American sport offers the athletically gifted individual (RIESS, 1990).

The reproduction of social inequalities is present in sport through the power of racial discrimination, men over women, and privileged over underprivileged. Moreover, people in positions of power and influence within sport institutions are manipulating democratic access. For this reason, traditional sport practice reproduces social inequality. Societies may seek ways in which sport might be democratized in an otherwise disparate society (KEW, 1990).

The anthropological definition of culture is that culture involves at least three components: what people think, what they do, and the material products they produce. Thus, mental processes, beliefs, knowledge, and values are parts of culture (BODLEY, 1994). All three components are inherent in sport. Therefore, sport is a form of culture. Football is a form of culture. Basketball is a form of culture. Freire defines culture as a superstructure which can maintain "remnants" of the past alive in the substructure undergoing revolutionary transformation and the occupation itself as an instrument for the transformation of culture (1970, p.159). In sport people are free to create and socialize. They are able to promote conscientização (consciousness) because they are not spectators; they are the actors and players, they are acting and playing in their own culture.

The main problem is that although sport can promote culture, we cannot take full advantage of this quality. We usually encourage children to practice sports without even knowing about the potential advantages. However, our focus is more related to entertainment and health, than it is related to its academic importance. Thus, we do not notice and explore the sports universe in an adequate way.

Freire's theories focus upon that education can aid in the social transformation by raising the critical consciousness of each person (FREIRE, 1973). Democratic learning opportunity for all students it is our responsibility as radical black people and people of color, and as white people, to construct models for social change (HOOKS, 1998). This is the significant role of education that Dewey (1964) articulated "Unless the schools of the world can engage in a common effort to rebuild the spirit of common understanding, of mutual sympathy and goodwill among all peoples and races, to exorcise the demon of prejudice, isolation, and hatred, the schools themselves are likely to be submerged by the general return to barbarism, which is the sure outcome of present tendencies if they go on unchecked by the forces which education alone can evoke and fortify" (p. 14).

"Sport can save or change my life" is a dream for many youths, poor and rich, but it is improbable for the majority. In Brazil and in the U.S. there were many examples of heroes who came from the poor, and who helped to promote that utopia. If someone from my favela or ghetto can succeed in sport, why not me?" The problem is that many children dream to be a professional player, which will never be able to achieve, instead that make focusing in education.

In sport people are still free to demonstrate culture. African Americans playing basketball in ghettos or Brazilian children playing football in streets have their own characteristics. Both sports have a cultural importance as a form for people to express themselves in ginga (body swings), jargons, clothes and style. This ginga is culturally developed and is not imposed. For this reason it is difficult to see Americans playing football like Brazilians and Brazilians playing basketball like Americans. They preserve their body capital. As Freire (1970) mentioned, the cultural process can consolidate the participation of the people in power. Sport is a dialogue between people and culture where people can be liberated from object to subject. They are liberating themselves from the cultural invasion and accepting their own realities and society.

The authors of this study estimate that is necessary to consider the socio-economic, political and regional context of Brazil. Also, it is necessary to consider the model of Brazilian sport in which educational institutions do not play a major role in countries such as the USA, Russia and 
China. So when we speak of biotype take into account the context in which it is inserted. Also, it is important to delve into the (un) social construction (s) meaning (s) of basketball and football in Brazil. For some people in Brazil, basketball is also a means to access the United States' universities. Another element to be considered is that Brazil, like the USA, is multicultural, which influences the motor skill and symbolic issue of sports.

\section{References}

ALLEN, J. B. Social motivation in youth sport. Journal of Sport \& Exercise Psychology, Dec 2003, Vol. 25, Issue 4, 2003.

ALVES, N.; GARCIA, R. L.; CARRANO, P. C. Bate-bola inicial. In Carrano (Ed.), Futebol: Paixão e política. Rio de Janeiro: DP\&A Editora, 2000.

ARBENA, J. Sport and society in Latin America. Connecticut: Greenwood Press, 1988.

BODLEY, J.H. Cultural anthropology: Tribes, states, and the global system. Mountain View, CA: Mayfield, 1994.

CALIL, Lucas. Triste realidade: no Brasil, $82 \%$ dos jogadores de futebol recebem até dois salários mínimos. Extra Online. Disponível em: <http://extra.globo.com/esporte/triste-realidade-no-brasil-82-dos-jogadores-de-futebol-recebem-ate-dois-salarios-minimos-6168754.html.> Acesso em 19 Set. 2014.

COAKLEY, J. Sport in society. Issues and controversies. St. Louis: The C. V. Mosby Company, 2009.

DEWEY, J. John Dewey on education. Chicago: University of Chicago Press, 1964.

DUNNING, E. Sport matters. Sociological studies of sport, violence and civilization. London: Routledge, 1999.

DUNNING, E. G., MAGUIRE, J. A., \& PEARTON, R. E. The sport process. A comparative and developmental approach. Champaign, IL: Human Kinetics Publishers, 1993.

FREIRE, P. Pedagogia do oprimido. São Paulo: Paz e Terra, 1970.

Education for critical consciousness. New York: Continuum, 1973.

. Pedagogia da esperança. Rio de Janeiro: Paz e Terra Press, 1994.

. Pedagogy of freedom. Ethics, democracy and civic courage. Lahman: Rowman \& Littlefield Publishers, Inc, 1998.

GRAHAM, R. The idea of race in Latin America, 1870 - 1940. Austin: University of Texas Press, 1990.
HARRIS, J. C. Interpreting young baseball: Players understanding of attention, winning, and playing the game. Research Quarterly in Exercise and Sport 54(4), 330-339, 1983.

HAYES, S.; STIDDER, G. Equity and inclusion in physical education and sport. London: Routledge, 2003.

HOOKS, b. Teaching to transgress. New York. Routledge, 1994.

INSTITUTO NACIONAL DE ESTUDOS E PESQUISAS EDUCACIONAIS. Censo Escolar 2003. Retrieved April 15, 2004, from www. inep.gov.br

KEW, F. Sport. Social problems and issues. Oxford: Butterworth-Heinemann, 1997.

LANDERS, D. M. Social problems in athletics: Essays in the sociology of sport. Urbana, IL: University of Illinois Press, 1976.

MACGREGOR, J. Why we play. Sports Illustrated, Volume 101, No. 12, 94-97. 2004, September 27.

MAHONEY, J.; CAIRNS, R. Do extracurricular activities protect against early school dropout? Development Psychology, 33(2), 241-253, 1997.

MARANHÃO, C. O país do futebol. Revista Veja, edição 1758 A, No. 26 A, 48 - 52, July, 2002.

MELO, V.A. Futebol que história é essa?. In Carrano (Ed.), Futebol: Paixão e política. Rio de Janeiro: DP\&A Editora, 2000.

NATIONAL CENTER FOR EDUCATION STATISTICS. Dropout rates in the United States: 2000. Retrieved on October 06, 2004, from < http://nces.ed.gov>.

RADER, B. American sports. New Jersey: Prentice Hall, 1999.

RIESS, S. A. Professional sports as an avenue of social mobility in America: Some myths and realities. In D. G. Kyle \& G. D. Stark (Eds.), Essays on sport history and sport mythology. College Station, TX: Texas A\&M University Press, 1990.

ROSSATTO, C. Social transformation and "popular schooling" in Brazil. Journal of the Association for Childhood Education International, 77, No. 6, 367-374, 2001.

SAGE, G. Power and ideology in American sport. Champaign. IL: Human Kinetics, 1998.

SAILES, G. A. Sport socialization comparisons among black and white adult male athletes and nonathletes. Doctoral Dissertation. University of Minnesota, 1984.

. The myth of Black sports supremacy. Journal of Black Studies, 21, p.480-487, 1991.

. A comparison of professional sports career aspirations among college athletes. Academic Athletic Journal, 11:2, p. 20-28, 1996. 
Betting against the odds: An overview of Black sports participation. Journal of African American Men, 2:2/3, p. 11-22, 1997.

SIMON, R. Sport and social values. Englewood Cliffs, NJ: Prentice-Hall, 1985.

SNYDER, E., \& SPREITZER, E. Social aspects of sport. Englewood Cliffs, NJ: Prentice-Hall, INC, 1978.

TALAMINI, J. T.; PAGE, C. H. Sport and society. An anthology. Boston: Little, Brown and Company, 2000.

TEICH, D. De onde eles vieram. Revista Veja, No. 28A, 36-42, July 17,2002

TUBINO, M. G. Dimensões sociais do esporte. São Paulo: Cortez Editora, 2001.

VILLORA, Sixto González et al. El concepto de iniciación deportiva en la actualidad. Retos. Nuevas tendencias en Educación Física, Deporte y Recreación, № 2009, 14-20.

WEIGAND, D. Social influences on youth sport motivation: relative influences of significant others. Paper presented at the $\mathbf{2 0 0 0}$ Congrés International de la SFPS. Paris. Abstract retrieved May 15, 2004, from http://www.unicaen.fr/unicaen/ sfps/ pdf/congres2000-symp50.pdf. 2000.

Data de recebimento 22/07/2014

Data de aprovação 15/08/2014

Data de aprovação 29/08/2014 